\title{
СОЦАЛЬНО-ЕКОНОМІЧНІ ВІДНОСИНИ
}

УДК 930

\author{
Оксана Валенене
}

Вильнюс

\section{ПРОБЛЕМА ИССЛЕДОВАНИЙ ПЕРВОГО ХРАМА В ВИЛЬНЮСЕ}

Локалізація і датування першого храму, напевно, одна з найпопулярніших, і в той же час, спірних тем в історії досліджень Вільнюса. На сьогоднішній день співіснує кілька гіпотез про його місцезнаходження, зовнішній вигляд, конфесійну приналежність. Мета даної статті - вивчити аргументи різних авторів з тим, щоб скласти найбільш повну картину того, що насправді являло собою перше святилище столиці Литви, і яку інформацію про планування середньовічного Вільнюса воно може надати.

Ключові слова: костел, християнство, конструкція зводів, містобудування.

П роблема локализации и датировки первого храма Вильнюса требует особого пристального внимания. Это здание имеет важное значение не только как отдельный археологический объект, но и как важный компонент городской среды в самом начале ее развития. То, когда, где и при каких обстоятельствах построен храм, обусловлено характером окружающего района, его конфессиональной, а может, и этнической принадлежностью. Поняв логику градостроителей, мы могли бы точнее представить, какие функциональные и социальные связи существовали между первыми центрами полиэтнического города.

В последнее время по вопросу локализации первого храма велась полемика между тремя учеными Литвы: исследователем кафедрального собора архитектором Напалеонасом Киткаускасом, автором моногра- 
фии «Основание Вильнюса» археологом Гедиминасом Вайткявичюсом и специалистом нумизматики Эдуардасом Ремецасом. Архитектор Н. Киткаускас полагает, что самым ранним храмом нужно считать остатки «квадратного здания», найденные в подземельях Кафедрального собора (рис. 1). По его мнению, это в середине XIII в. литовским королем Миндаугасом для его крещения построенный кафедральный собор. Позднее он мог использоваться как языческий храм (святилище Перуна), и только в 1387 г. был перестроен в Кафедральный собор [1, с. 202, 205]. Археолог Г. Вайткявичюс «квадратное здание» методом типологии бытовой керамики датирует примерно 1320 г. и связывает его с костелом, упоминаемым в письмах великого князя Гедиминаса [2, с. 61]. А Эдуардас Ремецас, не соглашаясь с оппонентами, утверждает, что им проведенное уточнение датировки большого пожара Вильнюсского замка начала $\mathrm{XV}$ в. позволяет «квадратное здание» отнести только ко времени крещения Литвы (1387 г.), а костел времен Гедиминаса (1320-е гг.) должен был стоять во внутреннем ограждении Нижнего замка [3, с. 83-84] (рис. 1).

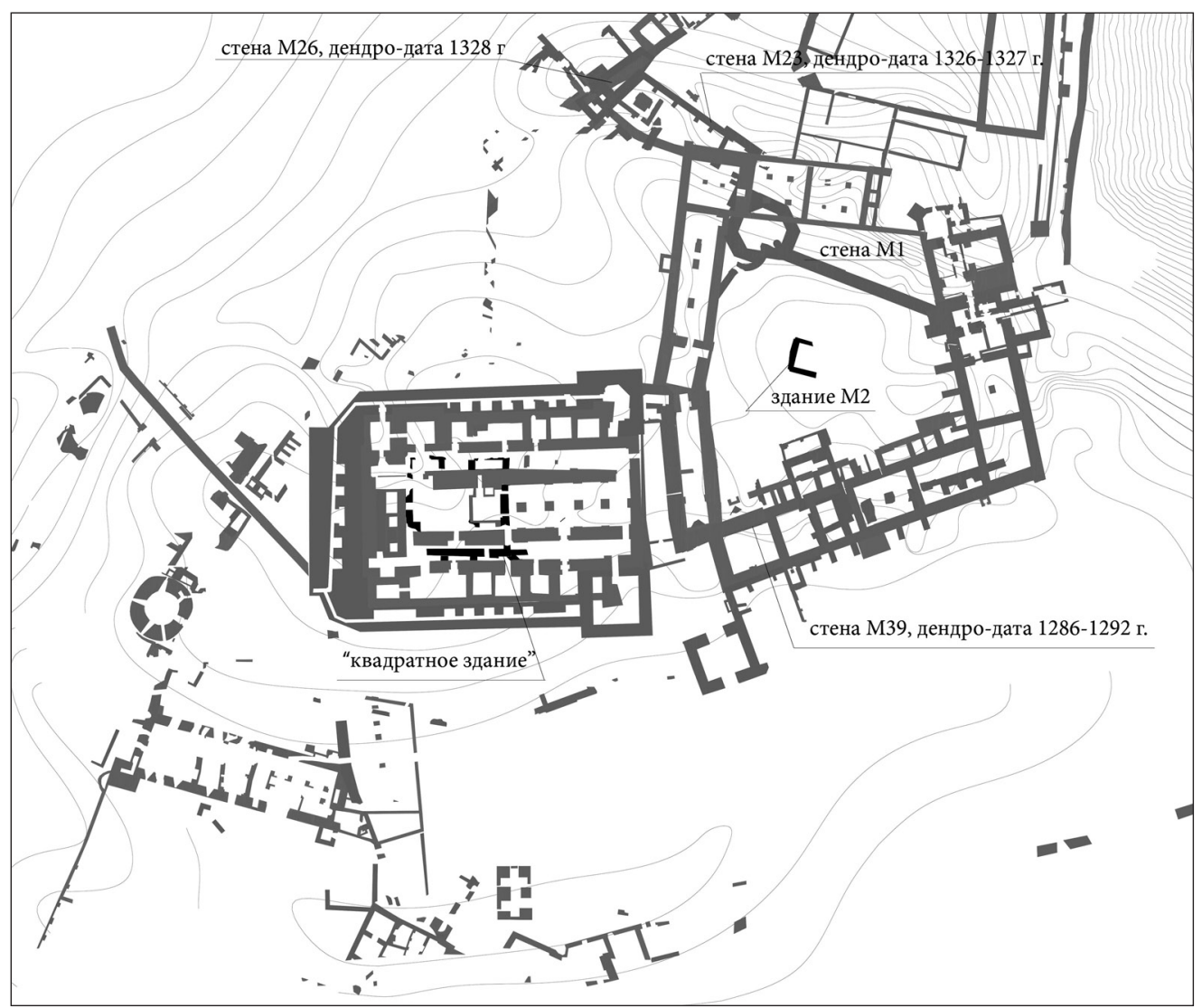

Рис. 1. План - ситуация замка великих князей литовских. Черным цветом выделены «квадратное здание» и здание М2. Серым цветом - все остальные каменные и кирпичные конструкции замка (автор О. Валенене) 
Желая составить свое мнение по данному вопросу, следует детально изучить и сопоставить аргументы, предлагаемые оппонентами. Нужно признать, что предложенная Н. Киткаускасом версия «кафедрального собора Миндаугаса» (середина ХІІІ в.) не имеет твердого основания хотя бы потому, что все остальные постройки замка на сегодняшний день датируются периодом не ранее конца XIII в. [4, с. 29]. А кафедральный костел без его окружающего замка и города трудно себе представить.

Н. Киткаускас в истории Кафедрального собора выделяет еще один период - «святилища Перуна» и связывает с этим в северном нефе найденную странную кирпичную лестницу (рис. 2, 3). Его аргументация такова: « $<. .>$ о назначении кирпичной кладки и двух лестниц второго этапа строительства в северном нефе сделать выводы нелегко. Лестницы заняли всю ширину северного нефа, значит в типичном католическом храме они мешали бы движению людей. Кроме того, ступени лестниц несильно стерты и невысоки. Судя по тому, что фрагмент западной лестницы прислонен торцом к северной стене, наружу по лестнице невозможно было попасть. Кроме того, основания лестниц крепкие, сложены из камней и опираются на твердый грунт, из чего видно, что построены на долгое время.

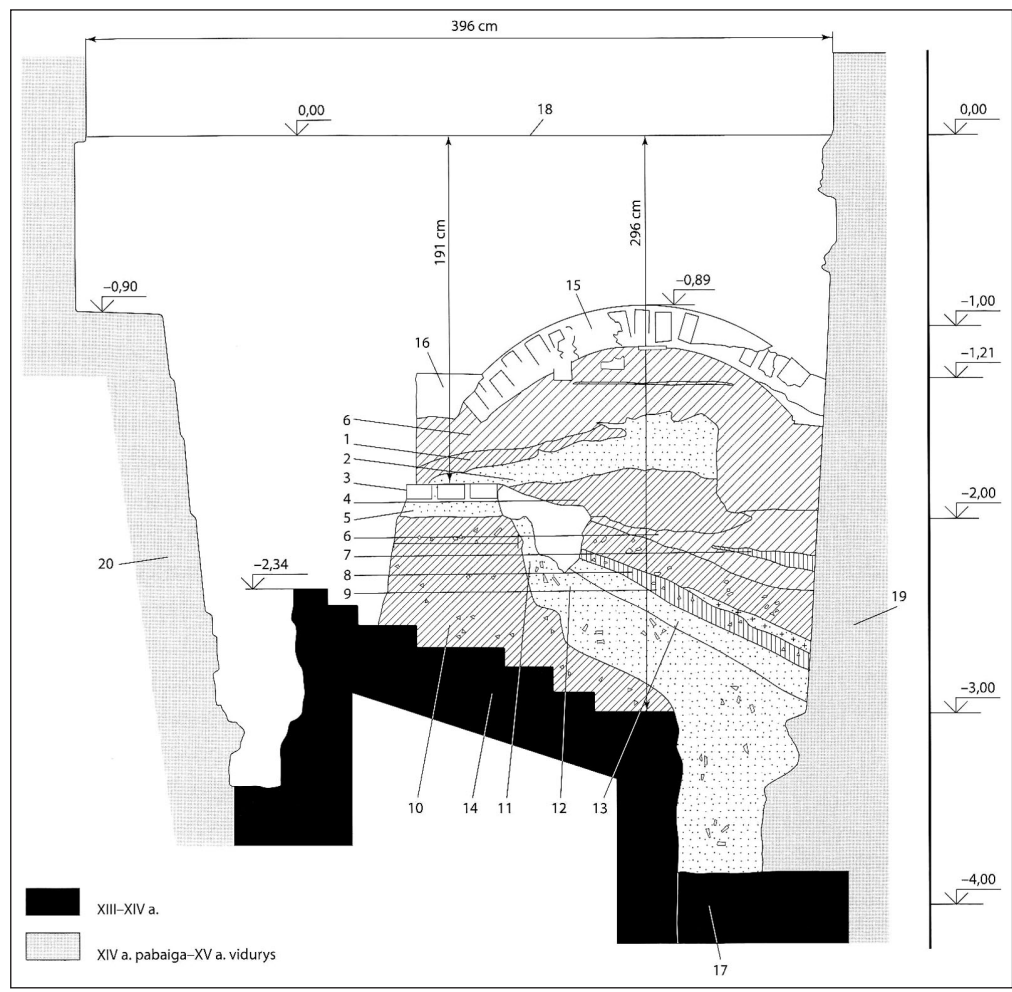

Рис. 2. Поперечный разрез северного нефа кафедрального собора.

Черным цветом обозначена «лестница предполагаемого языческого храма» [1, с. 192, 248 рис.] 


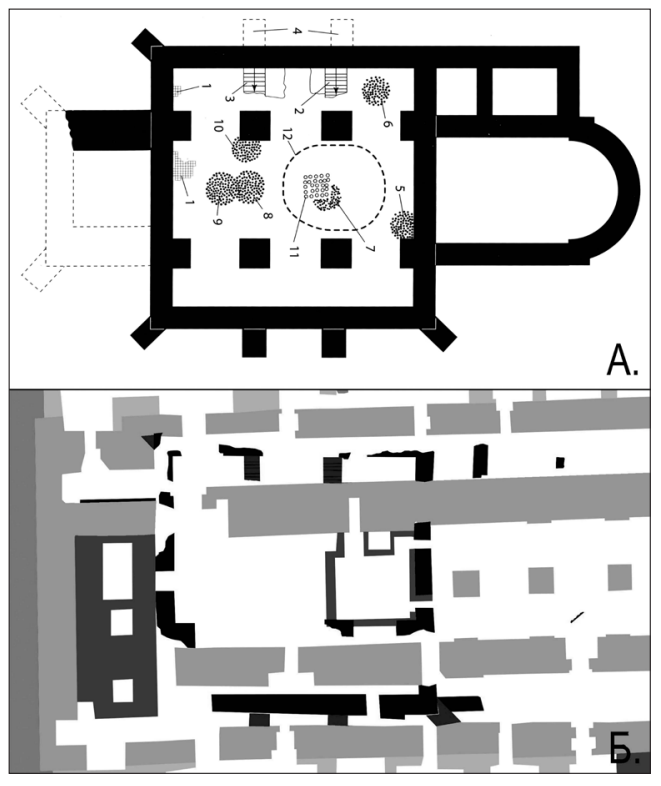

Рис. 3. План «квадратного здания»: А. Реконструкция Н. Киткаускаса [1, с. 223]; Б. Данные археологических исследований (автор О. Валенене) [9, с. 152]

В историографии есть ссылки на то, что на месте кафедрального собора стояло каменное святилище Перуна в виде ограждения без крыши <...> против часовни был построен ступенчатый алтарь <...> Очень ценная находка - в центре квадратного здания обнаруженные остатки четырех, как полагают, обрядных площадок из пережженной глины и нескольких жертвенных кострищ» [1, с. 202].

С точки зрения автора этой статьи, не стоит столь однозначно связывать каменные «лестницы» с языческим культом Перуна. Их назначение можно установить, детально изучив этапы перестройки «квадратного здания». И таких этапов, по мнению Н. Киткаускаса, было три. К первому стоит отнести само «квадратное здание». Ко второму - постройку двух лестниц и засыпку песком первого пола. К третьему - разрушение верхней части стен и сооружение новой кладки, а также строительство дополнительных часовен [1, с. 202]. Реконструкция третьего этапа причисляется к Кафедральному собору времен крещения Литвы (1387 г.) [1, с. 205]. Исследователь отмечает, что в строительстве использованы растворы двух типов: на первом этапе - коричневый, на втором и третьем - белый. Боковые и угловые контрфорсы отнесены к первому этапу, хотя, по словам автора, они могли быть возведены и «несколько позднее» [1, с. 201]. Такой вывод сделан на основании того, что контрфорсы были прислонены к стене, но с ней не соединены [1, с. 174]. Кроме того, обнаружены три уровня пола. Нижний, выложенный глазурованной плиткой, залегал на глубине 2,4-2,5 м. Следующий, простой кирпичной кладки, на глубине 1,93-2 м. И последний, также выложенный кирпичами - на глубине 1,73-1,81 м. Между «лестницами языческого храма» и полом второго уровня насыпана земля с осколками кирпича, черепицы и бытовой керамики XIV в. [1, с. 193-194]. Напалеонас Киткаускас пишет, что это было сделано по прошествии некоторого времени после окончания использования лестниц. Однако, по мнению автора этих строк, такое поведение строителей можно объяснить и другими целями. 
Как уже упоминалось, к «квадратному зданию» на каком-то этапе были пристроены боковые и угловые контрфорсы. Контрфорс - конструкция, служащая для нейтрализации силы бокового распора. Ее могут создавать либо разница поверхности грунта (например, в фортификационных ограждениях), либо - своды. В отличие от горизонтальных балок, которые на колонны давят сверху вниз, своды толкают верхнюю часть опоры вбок и наружу. Для того, чтобы конструкция не развалилась, сверху к ней добавляется вес (конструкция крыши и карниза, либо, в классической готике - специальные башенки пинакли). А сбоку, со стороны, в которую действует сила распора, ставится дополнительная опора - контрфорс. Таким образом, общая сила свода и верхней конструкции направлена не наружу, а на контрфорс, тем самым стабилизируя всю систему [5].

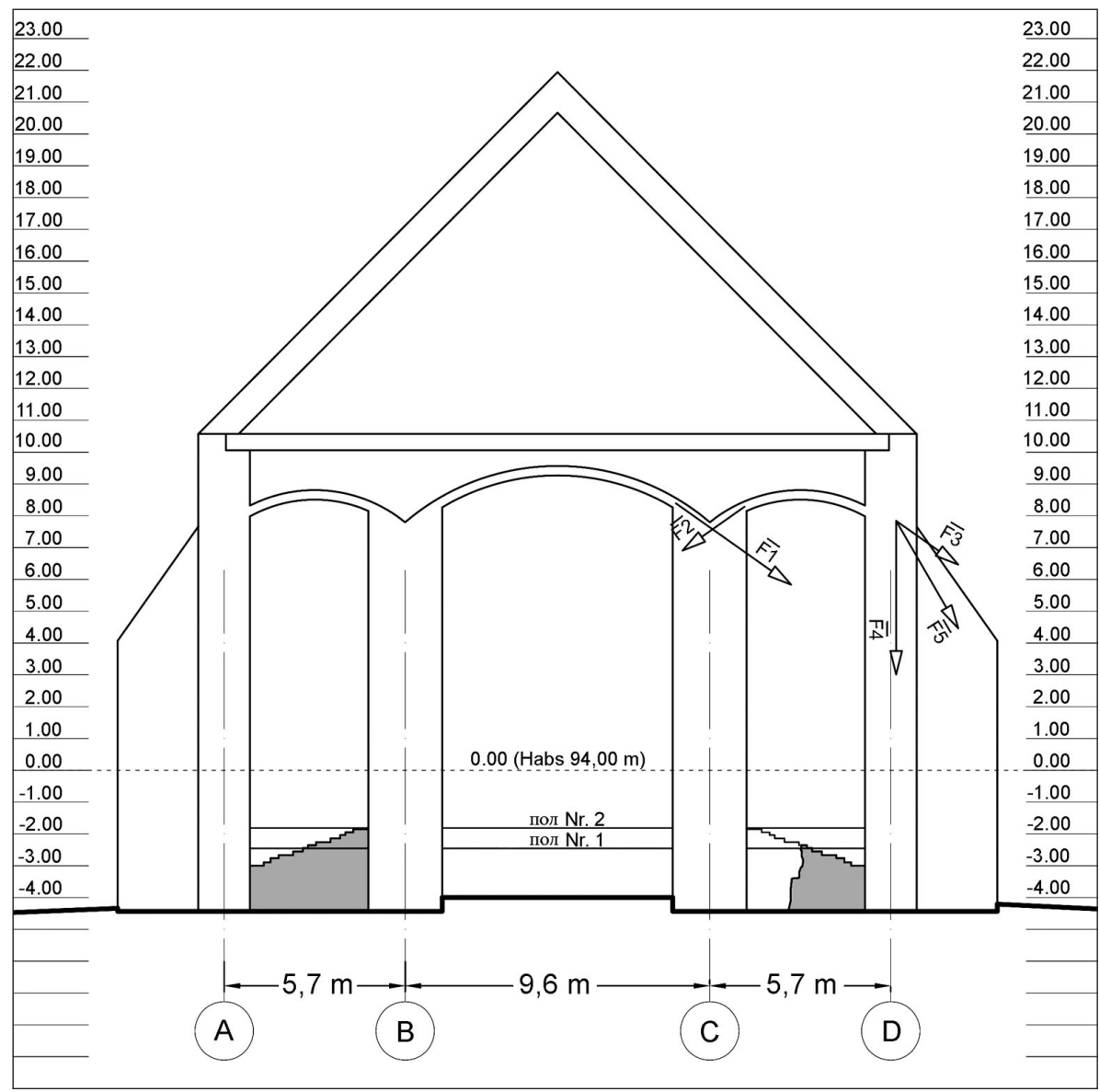

Рис. 4. Реконструкция «квадратного здания». Поперечный разрез. Принцип установки сводов и силы, действующие на конструкцию. Профиль сводов и пропорции издания реконструированы на примере Вильнюсского костела Св. Николая [6] (автор О. Валенене) 
На рис. 4 этот принцип показан на примере «квадратного здания». Реконструкция плана выполнена на основе неполных данных, поскольку во время археологических раскопок обнаружены не все фрагменты конструкции. Часть из них безвозвратно утеряна во время строительства готического кафедрального собора. Однако большой удачей было то, что по фрагментам удалось восстановить точный периметр здания. Кроме того, найдена одна из внутренних опор и на одной линии с ней оба боковых пилястра. Положение опоры находится на одной оси с боковым южным контрфорсом. Найден и второй южный контрфорс. Все эти данные позволяют достоверно реконструировать весь каркас здания, отображая недостающие детали симметрично относительно продольной оси главного нефа. Таким образом, нам известны все основные параметры конструкции: расположение, толщина, размеры внутреннего пространства.

Остается решить проблему реконструкции верхней части здания. Тот факт, что контрфорсы были пристроены не в начальном этапе, указывает на то, что в какой-то момент в уже построенном здании было решено возвести своды. Примерный профиль сводов и сверху к ним примыкавшие конструкции можно восстановить на основе ближайшего по времени и месту аналога - Вильнюсского костела Св. Михаила [6]. Как видим, сила распора боковых сводов (F3) компенсируется весом стены (F4) и боковыми контрфорсами (общая сила F5). Однако центральный и боковой своды не могут компенсировать друг друга. В здании типа базилики, в котором свод среднего нефа находится выше боковых, были бы добавлены дополнительные опоры - аркбутаны. В зальных зданиях, где все своды находятся на одном уровне, они сами поддерживают друг друга. А без дополнительных опор это возможно только при одинаковом весе сводов. Однако в «квадратном здании» пролет среднего нефа в два раза больше, чем пролеты боковых нефов. Поэтому логично предположить, что и сила распора, с которой он воздействует на колонну (F1), будет больше, чем у боковых сводов (F2). Поэтому при возведении сводов в «квадратном здании» возможны два решения. Строители могли бы разрушить старые колонны и уравнять ширину нефов. Но это негативно сказалось бы на интерьере, поскольку значительно бы уменьшилось главное пространство. С другой стороны, можно соорудить дополнительную опору снаружи центрального нефа, чем усилить колонну и стабилизировать конструкцию.

«Лестницы», найденные в северном нефе и причисленные ко второму этапу строительства, и есть такая конструкция. Их «ступени» - это уклон конструкции, сформированный кирпичами. Можно на примерах убедиться, что точно так же выкладывают и наружные контрфорсы. Следует обратить внимание на то, что обе лестницы находятся на оси с колоннами и с контрфорсами. Кстати, на то же обратил внимание и 
Н. Киткаускас [1, с. 195]. Тот факт, что в южном нефе «квадратного здания» таких конструкций не найдено, объясняется тем, что их уничтожили при строительстве стены готического костела, так же, как и большинство других фрагментов.

С этой точки зрения становится понятной вся ранее приведенная информация о «лестницах»: крепкий, опирающийся на устойчивый материк фундамент, маленькие непропорциональные, «мало стертые» (а может и совсем неиспользованные?) ступени, нефункциональность («лестницы» упираются в стену). Кстати, при их постройке использован белый, а не коричневый раствор, такой, как и в кладке третьего этапа.

Последний спорный вопрос - это соотношение «лестниц» и уровня пола. По мнению Н. Киткаускаса в пользу версии о языческом храме говорит то, что конструкция «лестниц» не могла использоваться в традиционном католическом костеле, потому что выступала над полом и препятствовала движению людей [1, с. 202]. Однако это предположение основано на том, что «лестницы» были видны в интерьере здания (они выступают над самым ранним полом). Но вспомогательную опорную конструкцию колонны строители могли хотеть спрятать под полом. Если мы реконструируем уклон сохранившейся части «лестницы» до места ее соприкосновения с колонной, то увидим, что непосредственно над ней находился пол второго уровня (глубина 1,93-2 м, сравнить рис. 2 и 4). Слой земли между «лестницами» и вторым полом следует считать не признаком запустения здания, как предлагается в версии Н. Киткаускаса, а выравнивающей насыпкой. И «лестницы», и земля, и второй пол должны принадлежать к одному этапу строительства, и связаны с усилением конструкции здания и возведением сводов.

Сопоставив данные, следует задуматься: а не была ли переделка верхней части стен, причисляемая к третьему этапу строительства, связана с той же реконструкцией? Ведь для того, чтобы качественно возвести своды, нужно привести в порядок и усилить кладку стен. То, что для стен использован кирпич другого формата, нежели для «лестниц», не может быть твердым аргументом в пользу более ранней датировки «лестниц». Вспомогательная конструкция, которая не видна в интерьере здания, может быть выложена вторично использованными кирпичами, например, теми, что остались после разборки верхней части стен. Однако этот вопрос можно оставить на будущее, поскольку задачей этой статьи было выяснить функцию конструкции «лестниц» и назначение «квадратного здания» в городе. А оно не имеет ничего общего с языческим святилищем Перуна.

По мнению автора статьи, версии о «Кафедральном соборе Миндаугаса» и «святилище Перуна» можно смело отбросить. Более убедительна гипотеза Г. Вайткявичюса, по которой «квадратное здание» - это 
костел, во времена великого князя Гедиминаса (1320-е гг.) принадлежавший миссии францисканцев. Однако и для этой версии нашлись контраргументы. Эдуардас Ремецас видит костел времен Гедиминаса во внутреннем ограждении дворца великих князей литовских, в здании M2 (рис. 1), а «квадратное здание» датирует временем крещения Литвы (1387 г.). Он пишет, что здание М2 «<..> фасадами ориентировано на северо-запад и юго-восток. Именно местоположение и ориентация здания показывают, что это здание было ни что иное, как культовое здание. В замках и крепостях жилые здания всегда строились около оборонных стен. <..> Чаще всего храмы строились, ориентируя в одну сторону: с запада на восток. <...> Только в виде исключения, когда храмы встраивали в уже застроенное пространство, их ориентация могла быть изменена $<\ldots>$ ». В этом контексте «квадратное здание» не может храмом времен великого князя Гедиминаса, поскольку «<..> установлено, что самая старая часть Нижнего замка - малое ограждение, чьи стены построены в начале XIV в. (самая ранняя дата - 1327 г.). Стены большого ограждения построены в середине - второй половине XIV в. Поэтому в неогражденном, или слабо огражденном месте костел не мог быть построен. Вовторых, как заметил Н. Киткаускас, в углах здания М2 нет контрфорсов, это указывает на то, что здание принадлежало к доготическому периоду. Между тем самое старое здание в подвалах кафедрального собора имеет контрфорсы. Такой же план имеет и фундамент костела Св. Анны, находящийся на территории Нижнего замка. А он, как полагают, построен в конце XIV в. Поэтому и самое старое здание, найденное в Кафедральном соборе, может быть датировано не ранее, чем концом XIV в. В-третьих, технология строительства здания М2, по которой во внутренней стороне стен делаются ниши, так же указывает, что это здание - самое старое из найденных в Литве. <..> Все данные указывают на то, что здание М2 не что иное, как францисканский костел, построенный около 1320 г. по приказанию великого князя Гедиминаса» [3, с. 83-84]. «Квадратное здание» датируется только временем крещения Литвы (1387 г.), потому что в слое пожарища, расположенном над полом первого этапа строительства, найдена бронзовая фигурка с гербом Капитулы (эта институция в Литве была сформирована в 1388 г.). Фигурка показывает, что слой пожарища сформировался уже после крещения Литвы, скорее всего, во время большого пожара 1399 г. [3, с. 86].

Рассмотрим аргументы Э. Ремецаса. Во-первых, местоположение здания. Согласно последним исследованиям, малое ограждение построено не в третьем десятилетии XIV в., а в конце XIII в. (самая ранняя дендро-дата деревянного фундамента - 1286-1292 m.) [4, с. 29]. А в третьем десятилетии, когда великий князь Гедиминас велел построить костел для францисканской миссии, уже была ограждена и «квадратное 
здание» окружающая территория [4, с. 29; 7, с. 49]. Поэтому, с точки зрения защищенности, окружение здания М2 равноценно окружению «квадратного здания». Положение здания в центре площади также не делает его храмом. В том же месте могут быть построены донжон, какое-либо важное здание. Кроме того, отождествляя здание М2 с храмом, нужно дополнительно оценить конфессиональную принадлежность и взгляды правителя, имеющего резиденцию в замке. Толеранция христианства, которую декларировал язычник Гедиминас, не означает, что христианский храм должен стоять в самом сердце замка. Поскольку приглашение христианской миссии было политическим шагом, а не выражением воззрений самого правителя, то и храм он построил не для себя, а для прибывших иноземцев, то есть не в центре замка. В этом контексте не могут служить аргументом предложенные Э. Ремецасом аналоги соседних земель: Гродно, Луцк и Новогрудок [3, с. 83]. Там в начале XIV в. христианство было давно устоявшейся религией и храм, стоящий в центре замка и предназначенный для окружения правителя, был общепринятым явлением. А в резиденции Гедиминаса это, скорее всего, было бы пощечиной для местной аристократии и языческого населения.

Сопоставив ориентацию «квадратного здания» и здания М2, надо отдать предпочтение первому из них. Фасады «квадратного здания» направлены почти идеально вдоль оси восток-запад, несмотря на то, что ориентация всех окружающих оборонных стен с ними не совпадает. А здание М2 ориентировано не по сторонам света, а всего лишь параллельно стене малого ограждения M1 (рис. 1). Поэтому, опираясь на слова Э. Ремецаса, именно ориентацию здания М2 нужно считать «исключением, когда храмы встраивали в уже застроенное пространство».

Следующий рассматриваемый аргумент - техника кладки стен и контрфорсы. Вполне возможно, что техника кладки указывает на то, что здание М2 старее, чем «квадратное здание». Но это всего лишь означает, что оно может быть построено в конце XIII - начале XIV в., раньше, чем в Литву по приглашению Гедиминаса прибыли францисканцы. А контрфорсов и в одном, и в другом здании на первом этапе строительства не было. Поэтому и эти аргументы надо отбросить.

Последний аргумент в защиту того, что «квадратное здание» не могло быть костелом времен Гедиминаса - бронзовая фигурка с гербом капитулы, найденная в слое пожарища конца XIV - начала XV в. Э. Ремецас пишет: «В самом старом квадратном храме возле западной стены, в нижних слоях был найден пол из глазурованной плитки. Над этой плиткой был насыпан слой желтоватого песка 20-25 см толщиной, а над ним обнаружен слой пожарища 5 см толщиной, выше которого был положен пол из красного кирпича. По мнению Киткаускаса, слой пожарища сформировался между «кафедральным собором Миндаугаса» и по- 
лом костела времен Йогайлы (конец XIV в.). Однако это предположение опровергает одна находка, которая помогла датировать слой. В 1974 г. в слое пожарища была найдена миниатюрная, величиной 23 мм, бронзовая фигурка. Она изображает коленопреклонённого человека со щитом в руках. На щите изображен герб - крест с расчлененной нижней частью и двумя коронами по бокам. То, что это - герб Капитулы, подтверждают известные печати Вильнюсской капитулы позднего времени. Как известно, Капитула была основана в 1388 г. Поэтому фигурка, найденная в слое пожарища, позволяет точно установить, что здание с полом из глазурованной плитки было костелом времен Йогайлы» [3, с. 86].

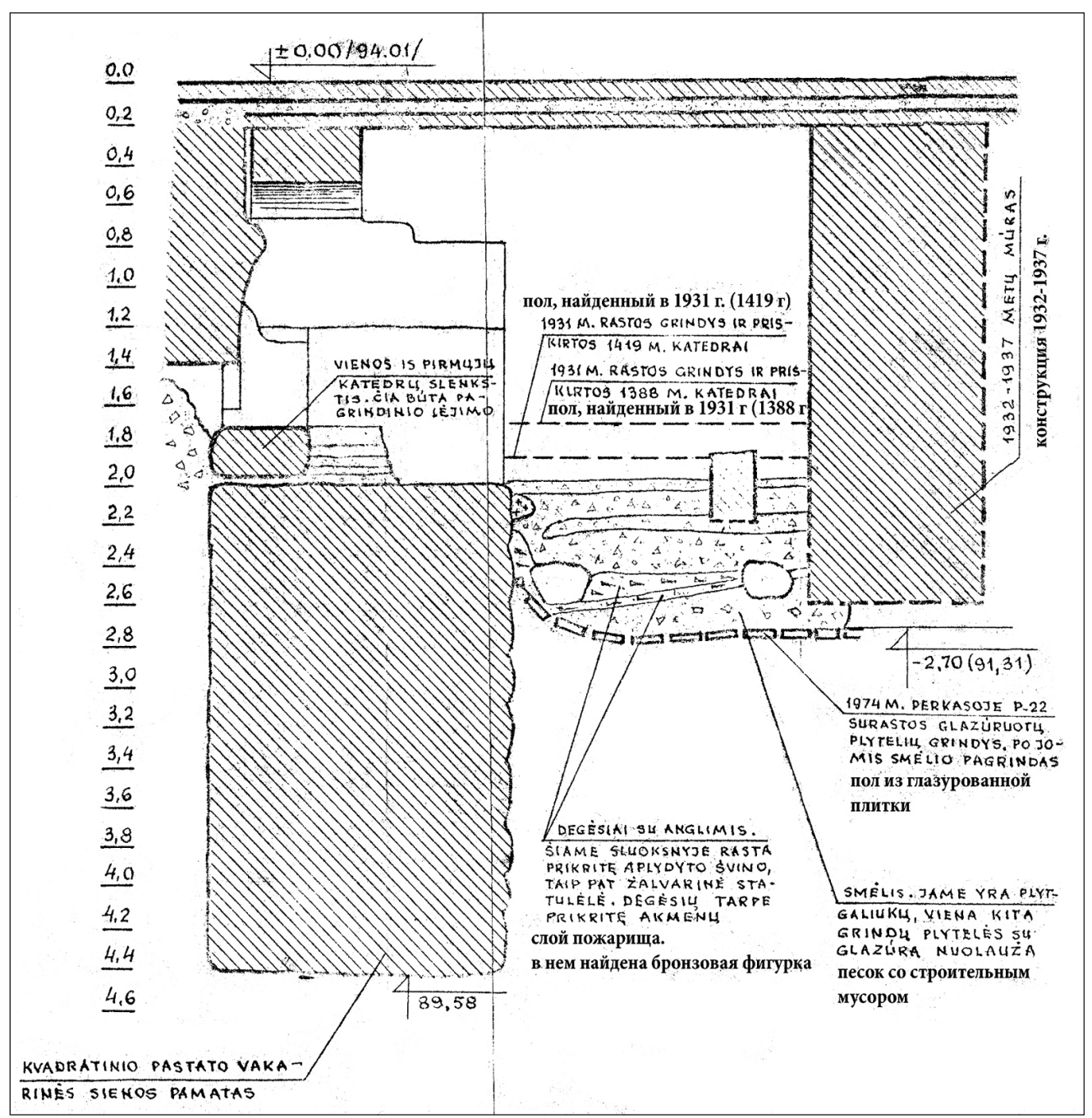

Рис. 5. Археологические раскопки в кафедральном соборе в 1974 г. Разрез раскопа Р22, в котором была найдена фигурка с гербом Капитулы [10, л. 32] 
Однако, судя по чертежам раскопок (рис. 5) на самом деле фигурка была найдена не над полом из глазурованной плитки, а над насыпным слоем песка, который ранее был причислен не к первому этапу строительства «квадратного здания», а к его реконструкции. Утверждение же Э. Ремецаса о том, что выше слоя пожарища был положен пол конца XIV в., основано не на стратиграфии конкретных культурных слоев, а на примерной высоте пола. Однако в раскопе Р22, в котором была найдена фигурка, выше слоя пожарища никакого пола обнаружено не было. Его место на чертеже обозначено пунктиром, на основе документов раскопок 1931 г. В реальности археологи в 1974 г. пола не обнаружили и первичной стратиграфии слоев не знали. Таким образом, можно лишь констатировать, что слой пожарища конца XIV - начала XV в. найден выше пола не построенного, а уже отремонтированного здания. И похоже, что слои, бывшие выше насыпного песка, были деформированы во время реконструкции 1931-1937 гг. На основании этих данных только пол второго уровня и реконструированное «квадратное здание» можно считать кафедральным собором времени крещения Литвы. Кстати, такая датировка совпадает со мнением Н. Киткаускаса [1, с. 202, 205].

Оценив и сопоставив аргументы всех участников полемики, нужно признать, что наиболее убедительной представляется позиция Г. Вайткявичюса. Хронология и пространственные параметры «квадратного здания» позволяют его связать с костелом, упоминаемым в письмах великого князя Гедиминаса в 1323 г. Правда, есть еще одно обстоятельство, которое может подкорректировать время строительства. Под восточной стеной найдено одно захоронение [8], более раннее, чем само здание. С одной стороны, эта находка показывает, что в момент постройки «квадратного здания» это место уже имело сакральное назначение. С другой стороны, заставляет предположить, что «квадратное здание» не было первым здесь построенным храмом. В своей монографии Г. Вайткявичюс предложил гипотезу, что на этом месте мог стоять деревянный храм, чья постройка была связана с визитом литовских посланников в Ригу в 1298 г. [2, с. 62]. По мнению автора этой статьи, не отбрасывая предложенной гипотезы, можно обдумать еще один вариант. Первый, возможно деревянный, храм действительно мог быть построен в 1320-1321 гг., как и писал Гедиминас в своем письме. А «квадратное здание» могло быть построено на том же месте около 1326-1328 г., во время большой реконструкции Нижнего замка [9, с. 145]. Однако это только предположение, которое не меняет главного: постройка христианского храма на укрепленной территории явно указывает на старания правителя организовать полиэтнический двор. Это обстоятельство принуждает усомниться в важном значении этой территории в каждодневной жизни местного языческого населения вплоть до конца XIII в., в противоречие 
устоявшемуся мнению. Разве могла новая, только начавшая утверждаться власть пренебрежительно играть религиозными верованиями ее поддерживающих людей и строить храм чужого вероисповедования на месте их главного культового центра? Думается, что более лояльным решением было бы как можно меньше на первых порах разрушать структуру поселения. А полиэтнический двор и первый христианский храм наиболее выгодно было бы расположить на территории от главного поселения удаленного форпоста, хорошо защищенного и контролирующего водные и сухопутные пути (рис. 6). Языческий же центр, с которым до сих пор было принято отождествлять место кафедрального собора, к сожалению, до сих пор не найден.

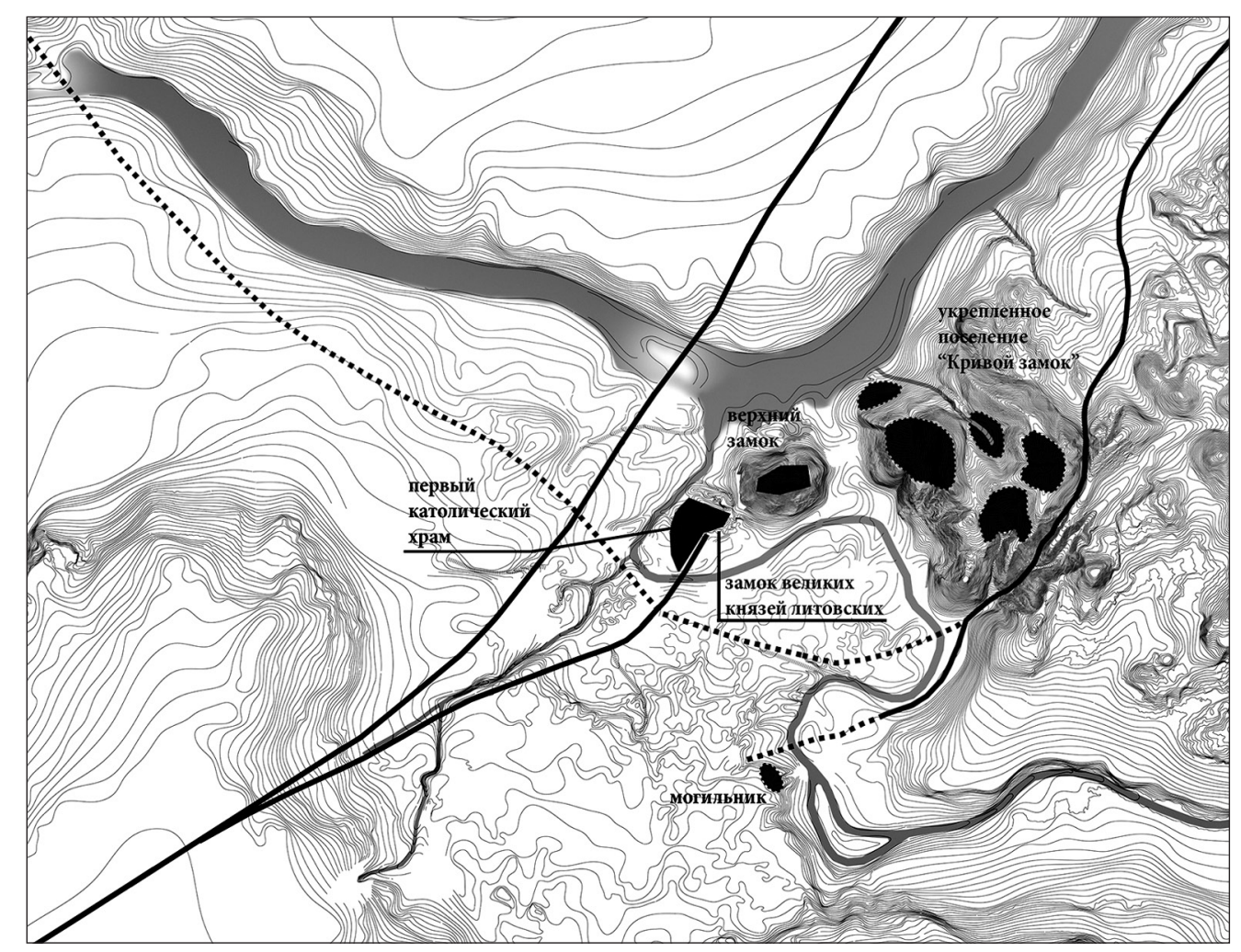

Рис. 6. План Вильнюса конца XIII - первой четверти XIV в. (автор О. Валенене) [9, с. 180]

\section{REFERENCES}

1. Vilniaus pilys. Istorija, statyba, architektūra / N. Kitkauskas. Vilnius: Mokslo ir enciklopediju leidybos centras, 2012. 312 c.

2. Vilniaus ịkūrimas / G. Vaitkevičius // Vilniaus sąsiuviniai. Vilnius: Lietuvos nacionalinis muziejus, 2010. т. $1.128 \mathrm{c}$. 
3. Vilniaus gaisro datavimo problematika: ar tikrai Vilniaus pilis sunaikino 1419 m. gaisras? / E. Remecas // Lietuvos pilys. Vilnius: Vilniaus piliu valstybinio kultūrinio rezervato direkcija. 2010. No. 6. C. 76-91.

4. Vilniaus Žemutinės pilies teritorija. LDK Valdovų rūmų vakarinio korpuso išorès archeologiniu žvalgymu I ploto i šiaurę nuo M-22 archeologiniu tyrimu ataskaita. / P. Blaževičius, P. Bugys. Vilnius, 2011, Vilniaus pilių direkcijos archyvas (VPDA), b. 222.

5. URL:http://gothic-vaults-edinburgh-thesis.weebly.com/about-the-project. html. [время просмотра 2014.08.07]

6. Šv. Mikalojaus bažnyčia. Apmatavimų brěžiniai / V. Abraitytė, J. Mininas, R. Putrimienė, O. Ribokaitė, I. Tuliševskaitè, Z. Turlaitė, M. Žvirblienė. Vilnius, 1983. Kultūros paveldo centro paveldosaugos biblioteka (KPCPB), f. 6, ap. 1, s. v. 15911-15920.

7. LDK Valdovu rūmų ir Vilniaus pilies teritorijos tyrimai 2002-2009 metais / G. Rackevičius // Lietuvos pilys. Vilnius: Vilniaus piliu valstybinio kultūrinio rezervato direkcija. 2009. No. 5. C. 44-62.

8. 1984-1988 m. Vilniaus Katedroje vykdytu archeologiniu tyrimu ataskaita. Šiaurinès navos brèžiniai. II dalis / A. Lisanka. Vilnius, 1989. LIIA, f. 1, b. 1937, br. 1. Šr. 1, kapas No. 7.

9. Vilniaus erdvinė struktūra viduramžiais: докторская диссертация. Гуманитарные науки. История $(05 \mathrm{H})$. / O. Valionienė. Lietuvos istorijos institutas, Klaipėdos universitetas, 2015.

10. Paveikslų galerijos (Vilniaus katedros) pastatas 1974, 1976 m. Žvalgomuju archeologiniu kasinèjimu ataskaita / I. Jučienè. Vilnius, 1982, Lietuvos istorijos instituto archyvas (LIIA), f. 1, b. 1062.

Oksana Valenene

\section{The problem of the research of the first temple in Vilnius}

Localisation and dating of the first temple are probably some of the most popular and at the same time most controversial topics in the research of the history of Vilnius. There are several hypotheses concerning its location, image, and confessional belonging. This article aims to examine and compare arguments of various researchers and to provide a more complete opinion on what the first temple of the capital of Lithuania was and what information it can provide about the urban environment of medieval Vilnius.

Key words: church, Christianity, vault construction, cities. 